Berkala Ilmu Perpustakaan dan Informasi, Vol. 15, No. 2, Desember 2019, Hal. 213-225 DOI: 10.22146/bip.36854

ISSN 1693-7740 (Print), ISSN 2477-0361 (Online)

Tersedia online di https://jurnal.ugm.ac.id/bip

\title{
Tingkat kesiapan Perpustakaan Universitas Gadjah Mada dalam penerapan summon discovery service
}

\section{Ulfaa Isthuufia}

Perpustakaan STIKes Maharani e-mail: isthuufia@gmail.com

Naskah diterima: 10 Juli 2018, direvisi: 14 Oktober 2019, disetujui: 24 Oktober 2019

\begin{abstract}
ABSTRAK
Pendahuluan. Layanan temu kembali informasi terus mengalami perkembangan semula layanan ini berupa katalog kartu, berubah menjadi katalog berbasis komputer (OPAC), dan kemudian menjadi discovery. Tujuan dari penelitian ini untuk mengetahui tingkat kesiapan Perpustakaan UGM dalam penerapan summon discovery service.

Metode Penelitian. Penelitian ini menggunakan metode kuantitatif dengan teknik pengumpulan data menggunakan survei.

Data Analisis. Analisis data menggunakan statistik deskriptif dan pengujian hipotesis menggunakan software SPSS.

Hasil dan pembahasan. Hasil penelitian menunjukkan kesiapan organisasi 2,55 yang dikategorikan "siap" dan tingkat kesiapan sumber organisasi diperoleh sekor 2,54 dikategorikan "siap".

Kesimpulan. Pada faktor kesiapan organisasi, indikator budaya organisasi yang paling tinggi dalam mempengaruhi tingkat kesiapan organisasi, disusul dengan struktur organisasi, dan dukungan manajemen. Untuk faktor sumber daya organisasi, indikator sumber daya manusia yang paling tinggi dalam mempengaruhi tingkat kesiapan sumber daya organisasi, disusul Teknologi Informasi dan Komunikasi (TIK), dan sumber daya keuangan.
\end{abstract}

Kata Kunci: Kesiapan; Pustakawan; Summon discovery service

\section{ABSTRACT}

Introduction. The information retrieval service continues to experience growth form of a card catalog, into a computer-based catalog (OPAC), and became discovery. The purpose of this study to determine the level of readiness of UGMLibrary in the application of summon discovery service.

Data Collection Method. This paper use survey with a quantitative approach.

Analysis Data. The data was analyzed by statistical descriptive and hypothesis testing using SPSS software.

Results and Discussions. The results showed of the organizational readiness of 2.55, which categorized "ready". The level of readiness of organizational resources obtained the score 2.54 and categorised "ready".

Conclusions. In the variable organization, the highest indicator was organizational culture followed by the organizational structure and management support. In terms of organization resourcesin, human resources were the highest followed by ICT, and financial resources.

Keywords: Readiness; Librarian; Summon discovery service 


\section{A. PENDAHULUAN}

Perkembangan teknologi informasi terus berkembang membawa banyak perkembangan baru di dunia perpustakaan. Perkembangan baru tidak hanya terjadi dalam bentuk fisik perpustakaan, tetapi juga dalam hal pengelolaan teknis perpustakaan. Menurut UU No. 432007 Pasal 14 ayat 3 tentang layanan perpustakaan, mewajibkan setiap perpustakaan mengembangkan layanan perpustakaan sesuai dengan kemajuan teknologi informasi dan komunikasi. Hal ini dilakukan pemerintah agar perpustakaan selalu mengikuti bekembangan zaman dan keberadaannya terus diminati masyarakat sebagai sumber informasi yang terpercaya.

Salah satu perkembangan perpustakaan adalah dibidang layanan perpustakaan, terutama layanan sistem temu kembali informasi. Semula layanan ini berupa katalog kartu, berubah menjadi katalog berbasis komputer (OPAC), dan kemudian menjadi discovery. Discovery atau biasa dikenal dengan istilah Web Scale Discovery merupakan fasilitas bagi pemustaka untuk memperoleh sumber informasi yang berada di perpustakaan melalui satu interface dengan satu single-search. Discovery ini muncul akibat kegelisahan perpustakaan akan hadirnya search engines (google, yahoo, dll) yang lebih diminati daripada perpustakaan sebagai alat penelusuran informasi, karena dianggap memiliki tampilan interface yang sederhana (single-search).

Search engine memiliki tampilan yang sederhana, yaitu hanya satu kotak pencarian (single-search) namun bisa menampilkan berbagai bentuk sumber informasi. Hal inilah yang membuat search engine menjadi sangat populer dikalangan pelajar. Meski perpustakaan sebagai pusat sumber informasi tersaingi dengan hadirnya search engine, namun perpustakaan tetap dipercaya oleh para pengguna karena dianggap memiliki sumber informasi yang lebih akurat. Salah satu kelebihan dari search engine yaitu mampu memberikan banyak sumber informasi dalam berbagai jenis format (teks, video, gambar, dan lain-lain.) kepada penggunanya. Mesti demikian banyaknya sumber informasi yang disediakan oleh search engine tersebut malah dianggap kurang sepesifik dalam memberikan sumber informasi. Deboris, dkk (2012) dalam penelitiannya mengatakan bahwa meskipun mahasiswa lebih memilih search engines, namun hasil yang diperoleh tidak sesuai dengan kebutuhan riset tingkat perguruan tinggi.

Discovery berbeda dengan OPAC (Online Catalog Perpustakaan), OPAC merupakan sarana temu kembali informasi yang hanya memberikan informasi koleksi yang dimiliki perpustakaan itu sendiri. OPAC tidak mampu memberikan informasi koleksi database yang dilanggan oleh perpustakaan. Biasanya perpustakaan juga akan membedakan antara database koleksi buku, database terbitan berseri, dan database karya ilmiah. Hal ini akan membuat tampilan interface setiap database menjadi berbeda, maka tak hayal jika pemustaka untuk mencari satu judul karya ilmiah akan berpindah-pindah ke dalam satu interface database yang berbeda-beda.

Berbeda dengan OPAC, discovery mampu menyajikan seluruh informasi yang dimiliki perpustakaan (katalog), serta koleksi yang dilanggan oleh perpustakaan (database ejournal dan e-book) melalui satu interface dengan satu single-search. Adanya fasilitas discovery ini memudahkan pemustaka tidak perlu berpindah-pindah dari satu database penelusuran ke database penelusuran yang lain. Pencarian informasi akan lebih mudah dan efisien dengan penelusuran satu single-search.

Penelitian sebelumnya mengenai kesiapan pernah dilakukan oleh Habiburrahman (2017), dengan judul Analisis Tingkat Kesiapan Implementasi Teknologi Informasi di Perpustakaan Pusat UIN Sumatera Utara Medan. Penelitian ini bertujuan untuk mengetahui tingkat kesiapan implementasi teknologi informasi (e-readiness) di Perpustakaan Pusat UIN Sumatera Utara Medan. Penelitian ini menggunakan metode campuran (mix method) kuantitatif dan kualitatif model concurrent triangulation. Analisis kuantitatif menunjukkan hasil yang siap untuk implementasi teknologi informasi (TI) di perpustakaan pada segmen kesiapan lembaga, kesiapan informasi, kesiapan 
infrastruktur, dan kesiapan lingkungan eksternal. Hal berbeda menunjukkan hasil yang kurang siap pada segmen kesiapan SDM, hal ini dikarena Perpustakaan Pusat UIN Sumatera Utara belum memiliki staf ahli yang memadai. Sedangkan analisis kualitatif mendapatkan hasil bahwa infrastruktur teknologi informasi di Perpustakaan Pusat UIN Sumatera Utara sudah cukup siap untuk implementasi teknologi informasi.

Priyanto tahun 2015 juga pernah melakukan penelitian kesiapan, dengan judul Readiness of Indonesian Academic Libraries for Open Access and Open Access Repositories Implementation: A Study on Indonesian Open Access Repositories Registered in OpenDOAR. Tujuan dari penelitian ini adalah ingin mengatahui kesiapan pustakawan akademik di Indonesia untuk penerapan Open Access dan implementasi repositori open access. Penelitian ini menggunakan teori Weiner tentang kesiapan organisasi untuk perubahan. Penelitian ini menggunakan metode campuran (mix method) kuantitatif dan kualitatif. Hasilnya menunjukkan bahwa pustakawan akademik di Indonesia cukup akrab dengan Open Access dan Open Access Repositories, namun pemahaman mereka tentang Open Access masih terbatas pada sifat teknisnya. Mereka juga tahu manfaat Open Access dalam kaitannya dengan kom unikas i i $1 \mathrm{miah}$ dan siap mengimplementasikan Open Access Repositories, namun implementasinya sebagian besar didasarkan pada tujuan untuk mencapai peringkat tertentu dalam rangking universitas kelas dunia dan Webometrics. Mereka menerapkan Open Access Repositories dengan keterbatasan infrastruktur, keterampilan, dan pengetahuan Open Access yang terbatas.

Penelitian yang dilakukan penulis ini memiliki topik yang sama dengan penelitian di atas, yakni sama-sama mengukur kesiapan teknologi informasi. Perbedaan penelitian ini dengan penelitian sebelumnya adalah penulis akan meneliti kesiapan perpustakaan dalam penerapan sitem temu kembali informasi yaitu summon discovery. Penelitian tentang kesiapan atau readiness terkait bidang perpustakaan di Indonesia masih sedikit, apalagi terkait layanan sistem temu kembali informasi discovery summon khususnya di Perpustakaan UGM masih belum pernah dilakukan.

Penelitian ini merupakan penelitian terbaru dan belum pernah dipublikasikan sebelumnya. Tujuan dari penelitian ini untuk mengetahui tingkat kesiapan Perpustakaan Universitas Gadjah Mada dalam penerapan summon discovery service. Penerapan discovery dalam penelusuran informasi belum banyak di lakukan di perpustakaan, sehingga dibutuhkan kesiapan semua pihak, baik pustakawan dan perpustakaan. Batasan topik kesiapan yang akan diteliti adalah terkait dengan Teori Weiner (2009) tentang kesiapan organisasi untuk perubahan Batasan informan yang diteliti adalah pustakawan PNS Perpustakaan UGM.

\section{B. TINJAUAN PUSTAKA}

Sistem temu kembali informasi berasal dari kata Informamation Retrival System (IRS). Sistem temu kembali informasi merupakan salah satu komponen yang harus ada di perpustakaan, sebagai sarana untuk mempermudah penemuan informasi bagi penggunanya. Sistem temu kembali informasi adalah sistem yang mampu menyimpan, mengambil, dan memelihara informasi. Informasi dalam konteks ini dapat terdiri dari teks (termasuk data numerik dan tanggal), gambar, audio, video dan objek multi media lainnya.

Sistem temu kembali informasi pada prinsipnya adalah suatu sistem yang sederhana. Misalnya ada sebuah kumpulan dokumen dan seorang pengguna yang memformulasikan sebuah pertanyaan (request atau query). Jawaban dari pertanyaan tersebut adalah sekumpulan dokumen yang relevan dan membuang dokumen yang tidak relevan (Hasibuan dan Andri, 2011). Menurut Trunojoyo (2010), tujuan dari sistem temu kembali informasi adalah untuk memenuhi kebutuhan informasi pengguna dengan mengambil semua dokumen yang mungkin relevan, pada waktu yang sama mengambil sedikit mungkin dokumen yang tak relevan. Sistem temu kembali informasi yang baik memungkinkan pengguna menentukan secara 
cepat dan akurat apakah isi dari dokumen yang diterima memenuhi kebutuhannya.

Discovery merupakan sistem temu kembali informasi generasi baru yang bukan sekedar katalog. Discovery pertama hadir pada 2007 milik OCLC Worldcat, diikuti pada pertengahan 2009 muncul Serial Solutions Summon. Pada tahun 2010 disusul tiga discvery dengan platform yang berbeda, yaitu: EBSCO Discovery Service (EDS), Innovative Interfaces Encore Synergy, dan Ex Libris Primo Central muncul (Vaughan, 2011). Discovery merupakan fasilitas bagi pemustaka untuk memperoleh sumber informasi yang berada di perpustakaan melalui satu interface dengan satu single-search (Priyanto, 2012).

Alat ini merupakan jawaban bagi perpustakaan yang memberikan solusi mengadapi gempuran dari search engine. Discovery merupakan sarana pencarian database perpustakaan dengan cara yang sama seperti alat penelusur search engine (Debonis, R., dkk., 2012). Discovery service adalah bentuk layanan perpustakaan yang memungkinkan seorang pemustaka dengan satu interface dapat menelusur berbagai sumber informasi baik yang ada di dalam perpustakaan (katalog perpustakaan) sendiri, di perpustakaan yang tergabung dalam discovery serta database yang dilanggan oleh semua anggota layanan discovery (Priyanto, 2012).

Hal senada juga diungkapkan oleh Vaughan (2011), bahwa discovery untuk lingkungan perpustakaan memiliki kapasitas yang lebih mudah dalam menghubungkan pengguna dengan repositori perpustakaan dengan jangkauan yang lebih luas. Ini mencangkup koleksi repositori lokal yang dimiliki perpustakaan sendiri dengan koleksi yang dilanggan baik koleksi berbentuk fisik maupun digital. Discovery merupakan layanan pencarian koleksi terintegrasi. Layanan ini digunakan untuk mempermudah pencarian koleksi dari sumber-sumber yang terpisah baik itu e-journal, e-book, maupun koleksi lainnya (Yunianto, 2016).

Menurut Kabashi, dkk. (2014), discovery memiliki lima kelebihan, sebagai berikut: (a) lebih memaksimalkan pemanfaatan sumber inormasi yang ada di perpustakaan; (b) antarmuka tunggal (single interface) untuk mencari berbagai sumber informasi; (c) hasil pencarian lebih spesifik untuk kebutuhan para pengguna daripada menggunakan search engine; (d) memungkinkan pengguna untuk melihat dan mengevaluasi apa yang tersedia dengan segera; dan (e) clear starting point for research, merupakan sumber informasi yang jelas untuk memulai penelitian.

Perpustakaan Pusat Universitas Gadjah Mada (UGM) juga melanggan discovery yang bernama Serials solutions summon atau biasa disebut Summon Discovery Service. Summon ini dikembangkan oleh ProQuest yang dibuat pada tahun 2008, dan diresmikan pada Januari 2009. Secara ringkas serials solutions summon dapat diartikan sebagai layanan penelusuran berskalaweb, merupakan indeks terpadu yang paling komprehensif, dan menghasilkan informasi yang relevan. Summon Discovery Service menyajikan informasi tanpa bias sehingga dapat menunjang dalam meningkatkan peran perpustakaan dalam proses penelitian yang dilakukan oleh para penggunnya.

Serials solutios summon memiliki empat manfaat yang diberikan kepada para penggunanya. Pertama, memberikan cakupan koleksi yang komprehensif. Pengguna perpustakaan memiliki kesempatan untuk menelusuri koleksi karena indeks database terpadu dengan kapasitas besar. Saat pengguna menggunakan discovery maka kemungkinan mendapatkan sumber informasi yang relevan akan dapat lebih terjamin, mengingat besaran database yang ada di dalam sebuah discovery. Kedua, sumber informasi mudah ditemukan. Pengguna perpustakaanakan memiliki pengalaman menemukan sumber informasi yang kaya dengan summon karena indeks terpadu yang dimilikinya. Model penelusuran single-search akan meningkatkan hasil penelusuran mempermudah penelusuran dan mengefisienkan waktu pemustaka dalam mencari sumber informasi yang dibutuhkan. Ketiga, menyajikan hasil relevan tanpa bias. Summon memberikan hasil yang sangat relevan dan tidak bias kepada pengguna. Pencocokan dan penggabungan catatan di antara vendor dan 
penerbit yang menghasilkan penemuan sumber informasi yang relevan dan mencegah perbuatan curang terhadap penyedia atau vendor manapun untuk lebih memprioritaskan karya tulis tertentu. Keempat, meningkatkan literasi informasi. Summon memberikan kemudahan dalam penelusuran informasi diharapkan sumber informasi yang tersedia di perpustakaan bisa lebih termanfaatkan. Hal ini juga diharapkan berdampak pada meningkatkan literasi informasi dikalangan masyarakat. Selain itu juga summon memfasilitasi pengguna untuk memperolah sumber informasi yang disarankan dari pihak perpustakaan terkait sumber informasi yang relevan.

Pengguna perpustakaan dapat menggunakan fasilitas pencarian Summon Discovery Service, untuk melakukan penelusuran informasi semua koleksi yang dimiliki oleh Perpustakaan Pusat UGM. Baik berupa konten lokal UGM (tugas akhir, artikel jurnal, pidato ilmiah, koleksi referensi, dll), maupun koleksi digital yang dilanggan perpustakaan. Selain itu katalog koleksi lokal perpustakaan juga sudah terintegrasi dengan summon, sehingga pengguna dapat menelusuri koleksi fisik yang dikelola oleh Perpustakaan Pusat UGM.

Pergeseran layanan temu kembali informasi dari katalog kartu, kemudian OPAC, dan yang terakhir discovery membutuhkan suatu kesiapan. Kesiapan atau yang biasa disebut dengan readiness harus dimiliki baik dari pustakawan dan perpustakaan sebagai organisasi. Menurut Weiner (2009), kesiapan didefinisikan sebagai kondisi di mana individu dalam organisasi siap secara psikologis dan berperilaku. Kesiapan adalah elemen kunci dalam menerapkan aktivitas, program atau kebijakan baru. Melaksanakan kegiatan, program, atau kebijakan baru berarti mengubah dari yang lama ke yang baru atau dari sesuatu menjadi sesuatu (Priyanto, 2015).

Teori Weiner (2009) tentang kesiapan organisasi untuk perubahan atau Theory of Organizational Readiness for Change (TORC), sebagai upaya untuk merespon kesiapan organisasi dalam kesuksesan untuk menghasilkan perubahan. Setiap kebijakan baru akan berjalan secara maksimal jika setiap individu di dalam organisasi sudah siap dengan kebijakan tersebut. Menerapkan kebijakan, program, atau aktivitas baru pada umumnya akan berhasil jika organisasi sudah siap.

Teori kesiapan organisasi untuk perubahan Weiner (2009) memandang individu sebagai bagian dari kerja tim dalam sebuah organisasi, sehingga cocok diterapkan untuk mengkaji kesiapan Perpustakaan UGM sebagai sebuah organisasi di mana pustakawan yang ada di dalamnya merupakan bagian dari kerja tim. Teori ini menjelaskan lima faktor yang mempengaruhi kesiapan sebuah organisasi yaitu: (1) budaya organisasi; (2) kebijakan dan prosedur; (3) pengalaman masa lalu; (4) sumber daya organisasi; dan (5) sumber daya organisasi.

Budaya organisasi berkaitan dengan dengan nilai dan keyakinan bersama yang berkaitan dengan identitas organisasi. Selain itu budaya organisasi juga berkaitan dengan nilainilai dan norma yang dianut dalam sebuah organisasi dan di jalankan dalam aktivitas sehari-hari. Menurut Desson (2010) budaya organisasi merupakan faktor kunci yang tidak hanya dalam mencapai tujuan organisasi, namun juga untuk menarik dan mempertahankan karyawan yang diinginkan, menciptakan citra publik yang positif, dan membangun hubungan yang baik dengan para pemangku kepentingan.

Organisasi atau lembaga menggunakan sumber daya organisasi sebagai sarana untuk mencapai tujuan. Sumber daya organisasi sebagai sejumlah pengetahuan, aset fisik, manusia, dan faktor-faktor berwujud dan tidak berwujud yang dimiliki atau dikendalikan organisasi. Ismail, dkk. (2012) juga menyatakan hal yang sama bahwa sumber daya organisasi dapat dikategorikan berwujud dan tidak berwujud. Sumber daya berwujud, misalnya, adalah manusia, fisik, organisasional dan finansial, sedangkan sumber daya tak berwujud mencakup sumber daya reputasi, peraturan, posisional, fungsional, sosial dan budaya. Namun sumber daya organisasi yang utama adalah koleksi atau sumber informasi, sumber daya TI, dan sumber daya manusia (Priyanto, 2015). 
Penggunaan sumberdaya organisasi yang optimal dalam menerapkan kebijakan baru akan memberikan manfaat dalam pencapaian efisiensi sesuai dengan target yang diharapkan. Menurut Tanny \& Putri (2017), salah satu masalah besar bagi organisasi adalah menemukan SDM yang profesional dan terampil dalam waktu yang cepat, baik dari segi teknologi maupum segi manajerial. Sehingga, salah satu tujuan dan strategi organisasi adalah mengembangkan kemampuan teknologi, manajerial, dan profesionalisme dari sumber daya manusia.

Pengetahuan dan keterampilan anggota organisasi sangat penting dalam proses implementasi suatu kebijakan baru dalam sebuah organisasi. Menerapkan sistem temu kembali discovery harus mempertimbangkan keahlian staf dan sumber daya lainnya terutama teknologi informasi untuk discovery (Priyanto, 2015).

Selain itu sumber daya TI merupakan elemen penting dalam penerapan kebijakan sistem temu kembali informasi. Perkembangan sistem temu kembali informasi di perpustakaan, khususnya discovery menuntut adopsi teknologi baru. Dibutuhkan penerapan teknologi dengan menyediakan perangkat keras dan perangkat lunak yang didukung dengan keterampilan dan kompetensi sumber daya manusia dalam menangani perubahan teknologi. Infrastruktur teknologi dan tenaga terampil profesional dibutuhkan untuk mendukung kebijakan sistem temu kembali discovery selama dan setelah implementasi.

\section{METODE PENELITIAN}

Metode analisis yang digunakan untuk mengkaji permasalahan penelitian ini adalah deskriptif kuantitatif. Penelitian ini merupakan penelitian deskriptif. Penelitian deskriptif sebagai prosedur pemecahan masalah yang diselidiki dengan menggambarkan dan melukiskan keadaan subyek dan obyek yang diteliti individu, lembaga, masyarakat, dan lainnya pada saat sekarang berdasarkan faktafakta yang tampak atau sebagaimana adanya (Nazir, 2011). Penelitian deskriptif juga bertujuan untuk menunjukkan kenyataan- kenyataan atau kondisi-kondisi yang ada tanpa terpengaruh oleh anasir subjektif dari penyelidik (Arikunto, 2009). Teknik pengumpulan data menggunakan survei dilakukan dengan menyebar kuesioner. Penelitian dilaksanakan di Perpustakaan Pusat Universitas Gadjah Mada, yang berlokasi di J1. Bulak Sumur, Daerah Istimewa Yogyakarta.

Populasi merupakan wilayah generalisasi yang terdiri atas obyek atau subyek yang mempunyai kualitas dan karakteristik tertentu yang ditetapkan oleh peneliti untuk dipelajari dan kemudian ditarik kesimpulannya, jadi populasi bukan hanya orang, tetapi juga obyek dan benda-benda alam lain. Populasi juga bukan sekedar jumlah yang ada pada obyek atau subyek yang dipelajari, tetapi meliputi seluruh karakteristik atau sifat yang dimiliki oleh subyek atau obyek itu (Sugiyono, 2013). Populasi yang menjadi subyek dalam penelitian ini adalah pustakawan PNS Perpustakaan Universitas Gadjah Mada.

Sample adalah bagian dari jumlah dan karakteristik yang dimiliki oleh populasi tersebut (Sugiyono, 2013). Sampel yang digunakan untuk penelitian kuantitatif adalah sampel jenuh. Teknik sampel jenuh diambil karena semua anggota populasi dijadikan sampel semua. Menurut data jumlah pustakawan PNS di Perpustakaan UGM tahun 2017 terdapat 81 pegawai. Kuesioner dibagikan ke 81 pustakawan, namun hanya 73 kuesioner yang kembali.

Kerangka pemikiran diadopsi dari teori kesiapan organisasi untuk perubahan milik Weiner (2009) dan teori kebutuhan milik Abraham Maslow. Gambar 1 merupakan kerangka pemikiran yang digunakan dalam penelitian ini.

\section{HASIL DAN PEMBAHASAN}

Analisis deskriptif digunakan untuk mengetahui tingkat kesiapan Perpustakaan Universitas Gadjah Mada dalam penerapan summon discovery service yang dilihat dari kategori skor jawaban responden. Data kuesioner yang diperoleh berdasarkan variabel sebelumnya diklasifikasikan menggunakan skala likert. Skala Likert digunakan untuk 
mengukur sikap, pendapat, dan persepsi seseorang atau sekelompok orang tentang fenomena soasial (Sugiyono, 2013). Menurut Nursalam (2017), dalam skala likert reponden dimintai pendapatnya dalam berbagai tingkat persetujuan (1-5) dari pernyataan yang disusun oleh peneliti. Pada penelitian ini mengunakan 3 skor skala likert yang disesuaikan dengan kebutuhan seperti tersebut pada Tabel 1.

Setelah itu akan ditentukan nilai rata-rata dari semua variabel untuk mengetahui tangkat kesiapan lembaga secara keseluruhan. Setelah itu akan ditentukan nilai rata-rata dari semua variabel untuk mengetahui tangkat kesiapan lembaga secara keseluruhan. Selanjutnya data kuesioner akan didukung dengan data wawancara sebagai konfirmasi dan eksplorasi yang lebih mendalam terkait tingkat kesiapan Perpustakaan UGM dalam penerapan summon discovery service. Berikut merupakan penjabaran analisis statistik deskriptif dari variabel organisasi dan sumber daya organisasi.

1. Analisis statistik deskriptif organisasi

Pada variabel organisasi memiliki tiga indikator, yaitu budaya organisasi, dukungan manajemen, dan struktur organisasi. Berikut merupakan penjabaran dari hasil yang diperoleh peneliti terkait kesiapan organisasi untuk menerapkan summon discovery service yang ada di Perpustakaan UGM.

Berdasarkan Grafik 1 jika dilihat secara keseluruhan kesiapan organisasi untuk menerapkan summon discovery service yang ada di Perpustakaan UGM sudah dalam level siap dengan perolehan nilai rata-rata 2,55. Indikator budaya organisasi yang paling tinggi dalam mempengaruhi tingkat kesiapan organisasi yaitu budaya organisasi dengan nilai $2,70 \%$, yang disusul dengan struktur organisasi sebesar 2,54\% dan dukungan manajemen sebesar 2,41\%. Berikut merupakan penjabaran dari masing masing indikator.

a. Budaya organisai

Pada indikator budaya organisasi memperoleh nilai 2,7 yang artinya dalam hal kesiapan organisasi Perpustakaan UGM siap dalam implementasi summon discovery service. Budaya berasal dari kata culture yang diadaptasi dari bahasa Latin, yaitu cult dan are. Kata cult yang artinya mendiami, mengerjakan, atau memuja, sedangkan are artinya sesuatu. Dapat diartikan juga bahwa budaya adalah tindakan dari Sumber Daya Manusia (SDM) yang menghasilkan sesuatu. Budaya dalam organisasi berkaitan dengan nilai dan keyakinan yang dianut bersama. Budaya yang ada pada suatu organisasi akan berbeda dengan organisasi lainnya. Oleh karena itu, kita tidak bisa menyamaratakan budaya yang ada disetiap organisasi.

Budaya organisasi yang ada di Perpustakaan UGM berkaitan dengan visi dan misi yang dianut, yaitu sebagai pusat rujukan informasi ilmiah baik bagi segenap civitas akademika dan masyarakat global. Salah satu cara untuk memberikan sumber informasi yang terpercaya adalah dengan berlangganan database (e-jornal, dan ebook). Perpustakaan UGM juga berlangganan sistem temu kembali terintergrasi summon discovery yang diperuntukkan bagi para penggunanya untuk memudahkan penelurusan informasi koleksi perpustakaan

Robbins (2013) mengatakan bahwa budaya organisasi memiliki tujuh karakteristik utama, yaitu: (1) Inovasi dan keberanian mengambil risiko (innovation and risk taking), (2) perhatian pada hal-hal rinci (attention to detail), (3) orientasi hasil (outcome orientation), (4) orientasi orang (people orientation), (5) orientasi tim (team orientation), (6) keagresifan (aggresiveness), serta (7) stabilitas (stability). Perpustakaan UGM berani melakukan inovasi dengan berlangganan summon discovery yang merupakan teknologi baru dalam sistem temu kembali informasi. Keberanian Perpustakan UGM ini tidak banyak diikuti oleh perpustakaanperpustakaan lain, khususnya perpustakaan perguruan tinggi, mengingat biaya yang cukup mahal juga untuk berlanggan discovery. 
b. Dukungan manajemen

Pada indikator dukungan manajemen memperoleh nilai 2,41 yang artinya dalam hal kesiapan organisasi Perpustakaan UGM siap dalam implementasi summon discovery service. Dukungan manajemen merupakan elemen penting dalam menerapkan sebuah kebijakan baru dalam sebuah organisasi. Dukungan manajemen ini dapat berupa motivasi, arahan, dan menyediakan sumber-sumber yang diperlukan kepada bawahannya. Pada tahap pengembangan sistem informasi, khususnya sistem temu kembali informasi manajemen atau pimpinan diharapkan secara aktif terlibat dalam menentukan perencanaan sistem informasi dan pada akhirnya pimpinan memberikan perhatian yang tinggi terhadap kinerja sistem informasi.

Setiap organisasi dalam usaha mencapai tujuan, dan mengukurnya sampai sejauh mana keberhasilan yang dapat dicapai, dan itu memerlukan dukungan manajemen puncak atau pimpinan (Susetyo dan Suherman, 2016). Pimpinan Perpustakaan UGM selalu memberikan dukungan untuk selalu berlangganan summon discovery service, hal ini dikarenakan pimpinan beranggapan bahwa summon merupakan senjata bagi perpustakaan dan pustakawan untuk melakukan penelusuran informasi dengan cepat dan akurat. Bentuk dukungan itu dengan tebuka terhadap saran dan masukan dari pustakawan terkait implementasi summon discovery service. Pimpinan juga sering memberikan pelatihan dan workshop yang berkaitan dengan penggunaan summon discovery service yang bertujuan untuk memberikan informasi kepada para pustakawan dan juga pemustaka. Partisipasi manajemen diharapkan dapat membantu meningkatkan kinerja dan perilaku yang baik bagi karyawan (Endaryati, 2016).

c. Struktur organisasi

Struktur organisasi merupakan cara untuk menata unsur-unsur yang ada di dalam organisasi dengan sebaik-baiknya untuk mencapai tujuan yang telah ditetapkan. Struktur organisasi berguna untuk membantu pimpinan dalam membuat kebijakan, karena di dalamnya tergambar jelas tugas dan wewenang dari setiap unitnya. Pada indikator struktur organisai memperoleh nilai 2,54 yang artinya dalam hal kesiapan organisasi Perpustakaan UGM siap dalam implementasi summon discoveryservice.

Struktur organisasi juga berkaitan dengan arus komunikasi yang ada di dalam komunikasi organisasi.

Arus informasi yang ada dalam komunikasi organisasi dapat dibagi menjadi dua yaitu komunikasi vertikal (ke atas dan ke bawah) dan komunikasi lateral (setara) (De Vito, 2011). Pola komunikasi yang ada di Perpustakaan UGM merupakan pola komunikasi vertikal, sehingga untuk melakukan komunikasi pada pimpinan pesan dikirim dari tingkat hierarki yang lebih rendah ke tingkat yang lebih tinggi. Terkadang hal ini membuat pesan sampai pada atas menjadi lama dan memperlambat tindakan.

Perpustakaan UGM belum memiliki unit khusus yang menaungi summon discovery, untuk penanganan summon ini masuk dalam bidang basis data dan jaringan. Terdapat tiga pegawai yang khusus menangani summon, namun ketiga pegawai tersebut juga memiliki jobdesk lain diluar pengembangan summon. Kurangnya pegawai yang menangani summon, membuat pengelolaan summon dirasa kurang maksimal dalam pemanfaatan fitur-fitur yang ada.

2. Analisis statistik deskriptif sumber daya organisasi

Organisasi menggunakan sumber daya organisasi sebagai sarana untuk mencapai tujuan. Penggunaan sumber daya organisasi yang optimal akan meningkatkan kinerja organisasi dalam mencapai efisiensi sesuai dengan target yang diinginkan. Sumber daya organisasi merupakan sarana yang dimiliki dalam sebuah organisasi baik itu berwujud dan 
tidak berwujud untuk mencapai tujuan. Sumber daya berwujud, misalnya, adalah manusia, organisasional dan finansial, koleksi atau sumber informasi, sumber daya TI. Sumber daya tak berwujud mencakup sumber daya reputasi, peraturan, posisional, fungsional, sosial dan budaya.

Kesiapan sumber daya organisaasi di Perpustakaan UGM diukur dengan tiga indikator yaitu Sumber Daya Manusia (SDM), TIK, dan sumber daya keuangan.

Berdasarkan Grafik 2, jika dilihat secara keseluruhan kesiapan sumber daya organisasi untuk menerapkan summon discovery service yang ada di Perpustakaan UGM sudah dalam level siap dengan perolehan nilai rata-rata 2,54. Berikut merupakan penjabaran dari masing masing indikator.

a. Sumber daya manusia

Sumber daya manusia merupakan elemen penting dalam organisasi. Perlunya manajemen yang baik dalam mengelola sumber daya manusia agar tidak terjadi gangguan dalam pencapaian tujuan organisasi. Betapa pentinganya organisasi memperhatikan pendidikan dan skill yang dimiliki oleh pegawainya. Pada indikator sumber daya manusia memperoleh nilai 2,7 yang artinya Perpustakaan UGM siap dalam implementasi summon discovery service. adanya SDM yang berkualitas sesuai bidangnya.

Berdasarkan Grafik 3, sebesar 2,70\% pustakawan berlatar belakang pendidikan S3 Ilmu Perpustakaan, 20,5\% pustakawan berlatar belakang pendidikan S2 Ilmu Perpustakaan, $28,70 \%$ pustakawan berlatar belakang pendidikan S1 Ilmu Perpustakaan, 26\% pustakawan berlatar belakang pendidikan Diploma Ilmu Perpustakaan. Sisanya merupakan pustakawan dengan pendidikan selain Ilmu Perpustakaan. Meskipun mereka tidak berlatar belakang Ilmu Perpustakaan pihak Perpustakaan UGM sering mengadakan pelatihan dan mengirim pelatihan pustakawan terkait Ilmu Perpustakaan.

Hal ini sudah sesuai dengan Standar Nasional Perpustakaan pada UU No 43 Tahun 2007 Pasal 11 dinyatakan bahwa kualifikasi tenaga perpustakaan perguruan tinggi adalah sebagai berikut: (a) minimal Strata 1 di bidang ilmu perpustakaan dan informasi, (b) terlibat aktif dalam organisasi profesi, dan (c) tenaga teknis minimal Diploma 2 serta memperoleh pelatihan kepustakawanan dari Lembaga pendidikan dan pelatihan terakeditasi. Serta sesuai dengan Undang-Undang No. 43 tahun 2007, yang menyatakan pustakawan adalah seseorang yang memiliki kompetensi yang diperoleh melalui pendidikan dan/atau pelatihan kepustakawanan serta mempunyai tugas dan tanggungjawab untuk melaksanakan pengelolaan dan pelayanan perpustakaan.

Menurut Putri \& Permana (2013) tenaga perpustakaan yang berlatar belakang pendidikan ilmu perpustakaan mempunyai pengaruh yang besar terhadap kepuasan pemustaka. Banyaknya pustakawan Perpustakaan UGM yang berlatar belakang pendidikan ilmu perpustakaan diharapkan bisa mengembangkan dan memajukan perpustakaan sesuai dengan kebutuhan pengguna. Agar perpustakaan selalu diminati oleh penggunannya dan dapat bersaing dalam memberikan sumber informasi yang bermutu.

b. Teknologi Informasi dan Komunikasi

Teknologi Informasi dan Komunikasi merupakan hal mutlak bagi sebuah institusi tak terkecuali Perpustakaan. Perpustakaan tidak bisa dipisahkan dari perkembangan Teknologi Informasi dan Komunikasi (TIK), termasuk dalam perkembangan sistem temu kembali informasi. Pada indikator TIK memperoleh nilai 2,57 yang artinya Perpustakaan UGM siap dalam implementasi summon discovery cervice. Perpustakaan UGM masuk dalam kategori siap diarenakan adanya sumber daya teknologi yang mendukung, dan kualitas mesin penelusuran informasi (discovery) sudah berjalan dengan baik.

Undang-undang nomor 43 tahun 2007 Pasal 19 ayat 2 menyebutkan bahwa pengembangan perpustakaan dilakukan berdasarkan karakteristik, fungsi dan tujuan, serta dilakukan sesuai dengan kebutuhan pemustaka dan masyarakat dengan memanfaatkan TIK. Universitas Gadjah Mada memiliki lembaga terkait dengan pengolahan data dan penyajian informasi yang bernama 
Direktorat Sistem dan Sumber Daya Informasi (DSSDI), sehingga mendukung penyelarasan sistem dan teknologi informasi di lingkungan UGM termasuk perpustakaan. Perpustakaan UGM sendiri juga memiliki Bidang Basis Data dan Jaringan yang mengelola dan melindungi informasi dalam basis data dan jaringan di Perpustakaan Pusat/Fakultas/Sekolah dan Unit Kerja lainnya.

c. Sumber daya keuangan

Sumber daya keuangan merupakan faktor yang penting dalam mempengaruhi kesiapan suatu organisasi. Pada indikator sumber daya keuangan memperoleh nilai 2,36 yang artinya Perpustakaan UGM cukup siap dalam implementasi summon discovery service. Setiap tahunnya Perpustakaan UGM mendapatkan alokasi pendanaan dari pemerintah melalui Bantuan Pendanaan Perguruan Tinggi Negeri Badan Hukum (BPPTNbh) Universitas. Sumber daya keuangan lainnya berasar dari Dana Masyarakat yang diterima oleh Universitas. Dana yang bersumber dari BPPTNbh utamanya dipergunakan untuk membiayai langganan database jurnal dan pengadaan $e$-book yang di dalamnya juga termasuk dana untuk berlangganan summon discovery.

Berdasarkan informasi dari Buku Laporan Tahunan Perpustakaan UGM Tahun 2017, total alokasi anggaran Perpustakaan Pusat sebesar Rp 17.327.606.456,- naik sebesar $19,55 \%$ dari tahun 2016, namun untuk tahun 2018 Perpustakaan mengalami pemangkasan sumberdaya keuangan. Perlu biaya yang cukup besar yang dikeluarkan Perpustakaan UGM untuk berlangganan summon discovery, sehingga merupakan hal sia-sia jika tidak banyak pustakawan dan pemustaka yang menggunkan summon dalam melakukan penelusuran informasi.

\section{E. KESIMPULAN}

Tingkat kesiapan Perpustakaan Universitas Gadjah Mada dalam penerapan summon discovery service yaitu meliputi dua faktor, yaitu kesiapan organisasi dan kesiapan sumber daya organisasi. Tingkat kesiapan organisasi untuk menerapkan summon discovery service yang ada di Perpustakaan UGM sudah dalam level siap. Inditator yang paling berpengaruh terhadap kesiapan organisasi adalah budaya organisasi diikuti struktur organisasi kemudian dukungan manajemen. Selanjutnya, tingkat kesiapan sumber daya organisasi untuk menerapkan summon discovery service yang ada di Perpustakaan UGM sudah dalam level siap. Indikator yang paling berpengaruh terhadap kesiapan sumber daya organisasi adalah sumber daya manusia diikuti sumber daya keuangan dan Teknologi Informasi dan Komunikasi.

\section{DAFTAR PUSTAKA}

Arikunto, S. (2009). Prosedur penelitian suatu pendekatan praktik ( 6 th ed.). Jakarta: Rineka Cipta.

Debonis, R., O'Donnell, E. \& Thomes, C. (2012). (Self-) discovery service: Helping students help themselves. Journal of Library \& Information Services in Distance Learning. 6, 235-250. https://doi.org/ 10.1080/1533290X.2012.705648

Desson, K. \& Clouthier, J. (2010). Organizational culture - Why does it matter? Presented to the Symposium on International Safeguards International Atomic Energy Agency Vienna, Austria November 3, 2010 (AEA-CN-184/315). Retrieved from http://www.iaea.org/ safeguards/symposium/2010/Documents/P apersReposit ory/315.pdf

De Vito, J. (2011). Human communication. New York: Pearson Education.

Endaryati, E. (2016). Pengaruh ukuran organisasi, partisipasi pengguna, dukungan manajemen puncak, program pelatihan dan teknik personal sistem terhadap kinerja sistem informasi akutansi (Survei UMKM Kota Semarang). Jurnal Ilmiah Komputer Akutansi, 9(1), 25-34.

Hasibuan, Z. A., \& Yofi A. (2011). Penerapan berbagai teknik temu kembali informasi berbasis hiperteks. Jurnal Komunikasi Ilmu Komputer dan Teknologi Informasi, 1(2), 110. 
Ismail, A.I., Rose, R.C., Uli, J., \& Abdullah, H. (2012). The relationship between organisational resources, capabilities, systems and competitive advantage. Asian Academy of Management Journal, 17(1), 151-173.

Kabashi, A., Peterson, C., \& Prather, T. (2014). Discovery services: A white paper for the Texas State Library and Archives Commission. Austin, TX: Texas State Library \& Archives Commission. Retrieved from https://www.tsl.texas.gov/ sites/default/files/public/tslac/lot/TSLAC WP_discovery_final_executivesummary.pdf.

Kowalski, G. (1945). Information retrieval systems: theory and implementation. Massachusetts: Kluwer Academic Publishers. Retrieved from https://mafiadoc.com/informationretrieval-systems-theory-andimplementation-the-_5a1d14dd 1 723dd27323b353d.html.

Nazir, M. (2011). Metode penelitian. Bogor: Ghalia Indonesia.

Nursalam. (2017). Metodologi penelitian ilmu keperawatan: pendekatan praktis. Jakarta: Salemba Medika.

Priyanto, I. F. (2012). Discovery. Makalah disampaikan dalam Seminar Nasional Perpustakaan Universitas Gadjah Mada, 3 Desember 2012. Diperoleh dari https://www.academia.edu/4437365/Disco very.

Priyanto, I. F. (2015). Readiness of Indonesian academic libraries for open access and open access repositories implementation: $A$ study on Indonesian open access repositories registered in OpenDOAR (Dissertation, University of North Texas).
Putri, A. W. \& Permana, A. (2013). Analisis latar belakang pendidikan tenaga perpustakaan terhadap kepuasan di Perpustakaan Poltekes Kemenkes Semarang. Jurnal Ilmu Perpustakaan, 2(1), 22-34.

Robbins, S. P. (2013). Organizational behavior 15thed. New Jersey: Prentice Hall.

Sugiyono. (2013). Metode penelitian pendidikan pendekatan kuantitatif, kualitatif, dan R \& D. Bandung: Alfabeta.

Susetyo, D. P., \& Suherman, A. (2016). Dukungan manajemen, kemampuan teknik dan pelatihan terhadap kinerja sistem informasi akuntansi. Simposium Nasional Ilmu Pengetahuan dan Teknologi (SIMNASIPTEK), 18-27.

Tanny, F. J. \& Putri, R. (2017). Sumber daya organisasi dan keunggulan bersaing berkelanjutan di perdana elektronik. AGORA, 5 (3). http://publication. petra.ac.id/index.php/manajemenbisnis/article/view/6091/5589

Trunojoyo, H. (2010). Sistem Temu Balik Informasi (Sebuah ContohImplementasi). Diakses dari http://husni.trunojoyo.ac.id/ wp content/uploads/2.

Undang-Undang Republik Indonesia No. 43 Tahun 2007 tentang Perpustakaan.

Vaughan, J. (2011). Chapter 1: Web scale discovery what and why? Library Technology Reports, 47(1), 5-11.

Weiner, B. (2009). A theory of organizational readiness for change. Implementation Science, 4(67), 1-9.

Yunianto, I. (2016). Panduan discovery search Perpustakaan UGM. Diakses dari http://lib.ugm.ac.id/ind/?page_id=3085 


\section{DAFTAR GAMBAR}

\section{ORGANISASI}

- Budaya organisasi

- Dukungan manajemen

- Struktur organisasi

\section{SUMBER DAYA \\ ORGANISASI}

- Sumber Daya Manusia

- Tekonologi Informasi dan Komunikasi

- Sumber Daya Keuangan

Gambar 1. Kerangka Pemikiran

\section{DAFTAR GRAFIK}

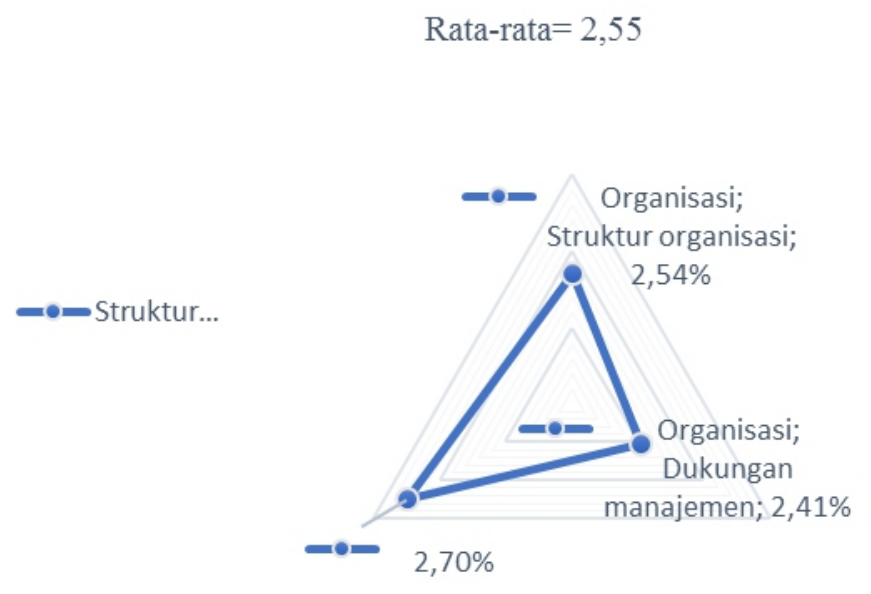

Grafik 1. kesiapan organisasi

Sumber: Hasil penelitian 2018 


\title{
DAFTAR GRAFIK
}

\author{
Rata-rata $=2,54$
}

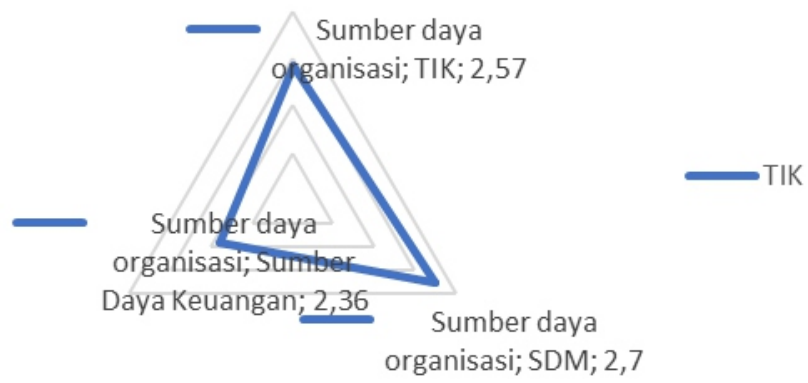

Grafik 2. kesiapan sumber daya organisasi Sumber Penelitian 2018

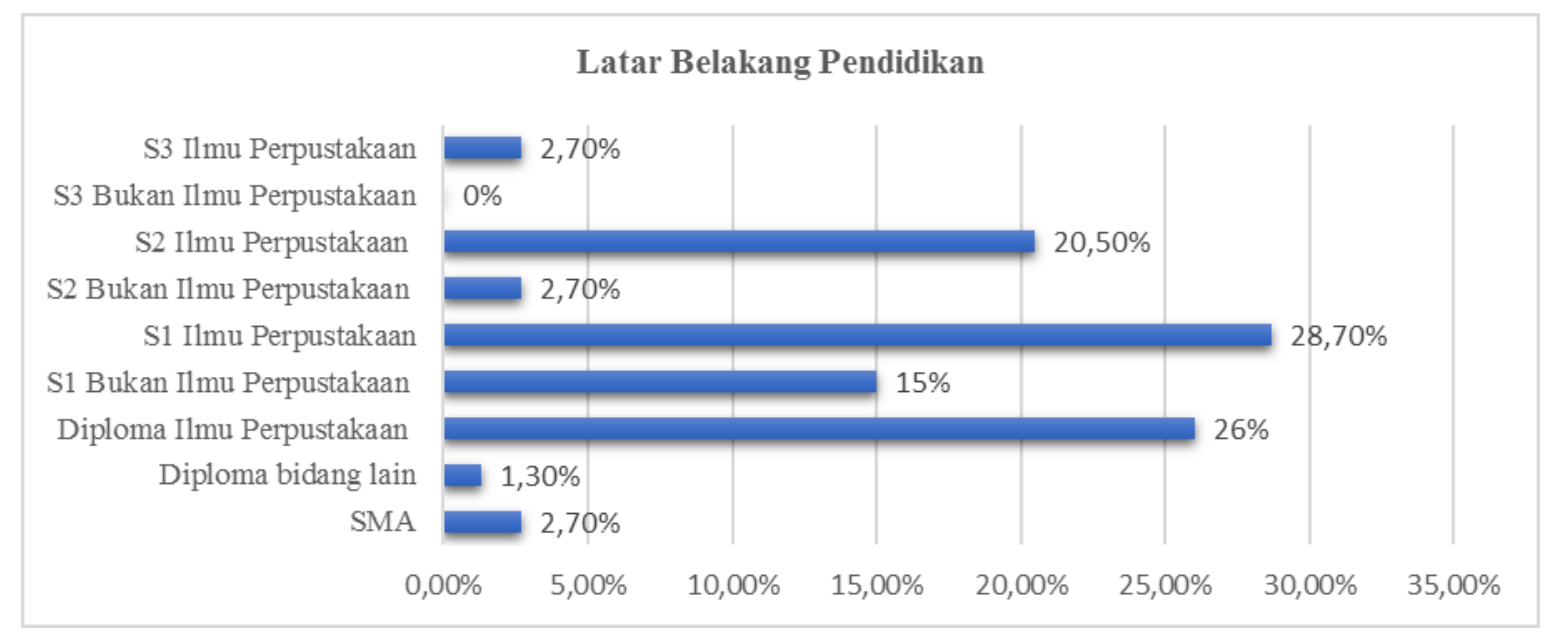

Grafik 3. Latar Belakang Pendidikan Responden

\section{DAFTAR TABEL}

Tabel 1. Kategori Berdasarkan Skor Skala Likert

\begin{tabular}{clc}
\hline No & Kategori & Skor \\
\hline $\mathbf{1}$ & Siap & $2,4-3$ \\
$\mathbf{2}$ & Cukup siap & $1,7-2,3$ \\
$\mathbf{3}$ & Kurang siap & $1-1,6$ \\
\hline
\end{tabular}

